\title{
The descendants of Lat. ipse in Romanian
}

\author{
Andra Vasilescu* \\ Faculty of Letters, University of Bucharest, 5-7 Edgar Quinet St., 010017 Bucharest, Romania \\ "Iorgu Iordan - Al. Rosetti" Institute of Linguistics, 13 Calea 13 Septembrie, 050711 Bucharest, Romania
}

\section{Article info}

History:

Received May 16, 2017

Accepted June 3, 2017

Published September 30, 2017

Key words:

Romanian

Lat. ipse

history of forms

history of uses

intensifier

focal particle

\begin{abstract}
The Latin demonstrative ipse had different evolutions across the Romance languages, with Romanian being the one that preserved most of the source-language uses and enriched them with new ones. This article describes the evolution of the forms and functions of $\hat{i n s} s_{1}, \hat{i n s} s_{2} / i n s$, ins( $(\breve{a})_{3}$, insul, nusul, dinsul, adins, insussi, and of the bound focal particle $-s, i$ in Romanian. The analysis is based on a rich corpus of old Romanian and non-standard regional varieties of modern spoken Romanian. The most significant phenomena in old Romanian compared to Latin are the proliferation of forms, the preservation of the old uses and the emergence of new ones, semantic enrichments, and a large number of lexical-functional synonymies. During the old Romanian period, the formfunction correlations gradually changed, syntactically conditioned variants and differential prepositional object marking emerged, new meanings developed as contextual effects of the focal prototype, the syncretisms with the reflexive and reciprocal pronouns were limited, and the textual deictic was grammaticalized as an adversative conjunction. In modern Romanian, the number of ambiguities has decreased and register differences have appeared. The evolution of the Latin ipse in Romanian illustrates a case of poligrammaticalization and polimorfism, which is not singular in the history of the neo-Latin idioms.
\end{abstract}

\section{Preliminary remarks}

In classical Latin, ipse ( $\left.{ }^{*} i p s u s\right)$ was a demonstrative pronoun and functioned as a (contrastive) noun phrase/ sentence focalizer, and sometimes as a reflexive pronoun or, in combination with reflexive pronouns, as a reciprocal. In late Latin it became a synonym of hic, and was used as a textual deictic, i.e. a deictic having a sentence as antecedent/subsequent term (Ernout \& Thomas, 1959, p. 187-191; Väänänen, 1981, p. 120; Woodcock, 2005, p. 25-26; Baños Baños, 2009, p. 181-182). The subsequent evolution of ipse in Romance was divergent: in most Western languages (French, Italian, Spanish, Portuguese) it disappeared; in others (Sardinian, partly the Gascon area, and Catalan), it developed into a definite article, while Romanian is the only language which preserved and enriched its forms and pronominal uses (Densusianu, 1938, p. 176; Sala, 2001, s.v.). In present-day Romanian, it displays several contextual functions.

\section{From Latin to old Romanian}

Compared to Latin, the descendants of ipse in old Romanian show the following features described below: the proliferation of forms $(\$ 2.1)$, the preservation of uses $(\$ 2.2)$, the emergence of new usages $(\$ 2.3)$, polifunctionalism $(\$ 2.4)$, and a rich network of lexical-functional synonymies $(\$ 2.5)$.

\subsection{Proliferation offorms}

There are several formal descendants of the Latin ipse in old Romanian: ins $s_{1}(1)$, ins $s_{2} /$ ins (2), ins(ă) (3), insul (4), nusul (5), dînsul (6), adins (7), însuşi (8).

\footnotetext{
*Email address: vasilescu.andra@gmail.com.
} 
(1) a. iubeaște vecinul tău ca

love.IMP.2sG neighbour.DEF.ACC.M.SG your.M.SG as

ins tine $\left(\mathrm{CC}^{1} .1567-8,90^{\mathrm{v}}\right)$

INNS.M.SG you.ACC

'Love your neighbour as yourself'

b. inși ni le tragemu $\left(\mathrm{CC}^{2} .1581,285\right)$

INNS.M.PL CL.DAT.1PL CL.ACC.F.3PL strive.PRES.1PL

'we ourselves strive for them'

(2) a. patr-înşi $\quad\left(\mathrm{CC}^{2} .1581,54\right)$

four $=\hat{I N S S . M . P L}$

'four fellows'

b. doi inş $\left(\mathrm{CC}^{2} .1581,367\right)$

two INS.M.PL

'two fellows'

(3) Cătră tine alerg; însă fata-mea, [...]

towards you.ACC.2SG run.PRES.1SG îNS.F.SG daughter.F.SG=my.ACC.F.SG

eu o lăsaiu acasă ( $\mathrm{CC}^{2} .1581$, DA, s.v.)

I CL.ACC.F.3sg leave.PS.1sg home

'I'm running to you; but my daughter [...], I left her at home'

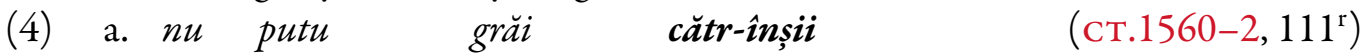

not can.PS.3SG speak.INF towards=îNS.DEF.M.PL

'he was not able to speak to them'

b. nu e intr-însele alte nemică (CCat.1560, $2^{\mathrm{r}}$ )

not is in $=\hat{I} N S$.DEF.F.PL any.F.PL nothing

'there is nothing else in them'

(5) a. Si era Dumnezen cu nusul (CL.1570,26)

and was God with NUS.DEF.M.SG

'and God was with him'

b. cu nusa leagă cătuşile de

with NUS.DEF.F.SG fasten.PRES.3PL chain.DEF.F.PL as

o țepenesc $\quad\left(\mathrm{CC}^{2} .1581,294\right)$

CL.ACC.F.3SG fix.tight.PRES.3PL

'and they fasten it with chains and fix it tight'

(6) a. văzu Iisus pre Nathanail viind cătră sine see.PS.3sG Jesus DOM Nathan come.GER towards self

și grăi dins (VRC.1645,31)

and speak.PS.3sG DINS.M.SG

'Jesus saw Nathan coming towards him and spoke to him'

b. o aduseră pre dînsa

CL.ACC.F.3SG bring.PS.3PL DOM DÎNS.F.SG

la Faraon (BB.1688, DA, s.v.)

at Pharaoh

'they brought her to Pharaoh'

(7) a. adinsu voi iubosti aibind (CV.1563-83,159 $)$

ADINSU you.PL love.ACC have.GER

'loving each other' / 'having love for each other'

b. iertîndu-vă adinsu voiș

forgive.GER $=\mathrm{CL} . \mathrm{ACC} \equiv \mathrm{DAT} .2 \mathrm{PL} \quad$ ADINSU $\quad$ youș.N.2PL

(NT.1648, DA, s.v.)

'forgiving each other' 


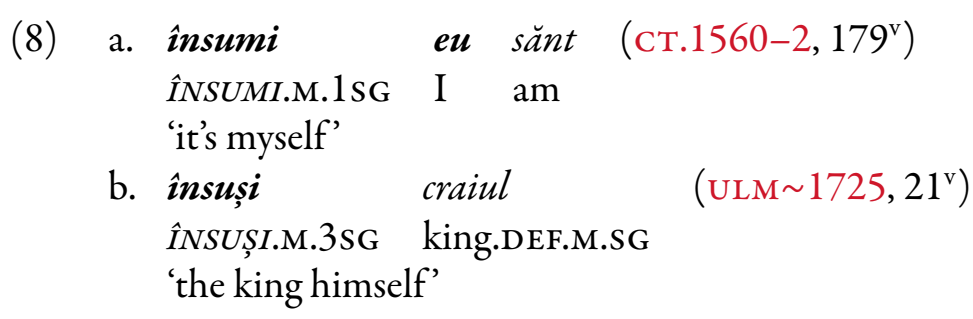

Of all these forms, $\hat{i} n s_{1}, \hat{\imath} n s_{2} /$ ins, $\hat{i} n s(\breve{a})$ are the direct descendants of Lat. ipse, while the others are compounds in old Romanian with îns plus the definite article (insul $<\hat{i n s}+-u l)$ or with îns $( \pm$ definite article) and various prepositions (adins $(u l)<a d+\hat{\imath} n s+(-u l)$; insuşi $<\hat{i n s}(u)+-$ și; nusul $<$ cu nus $+-u l<c u+$ $\hat{i n s}+-u l$; dinsul $<d e+\hat{i n s}+-\mathrm{ul})$. The definite forms were more frequent than the indefinite ones, and insuşi fully replaced ins by the end of the $18^{\text {th }}$ century (see details in Vasilescu, 2015, p. 330-332).

The etymology of the compound insuşi (Engl. 'itself/himself' used as an intensifier) has been a matter of controversy among the Romanian linguists, who proposed three hypotheses: (i) ins + the dative reflexive și (< Lat. sibi); (ii) ins + the deictic adverbial -și (< Lat. sic); (iii) ins $+-s$, i, the clitic form of Lat. ipse (for details see Manoliu-Manea, 1987; Zafiu, 2012). The bound focal particle -și attached to îns and many other semantic subtypes of pronouns (eluşi, mineși, săiși, sineși, același, cevași, careși), adverbs (atunceși, aciiași) and numerals (întîiași). Most of these forms disappeared during the $18^{\text {th }}$ c., others (întîiaşi, cevași) persisted in some regional varieties of spoken non-standard Romanian, while acelaşi and insuşi have been completely taken over by the system of modern Romanian. Același lexicalized as a demonstrative pronoun/adjective of identity (Engl. 'the same'), inflected for gender, number, and case (NOM $\equiv$ ACC: m.sg. acelaşi; f.sg. aceeași; m.pl. aceiași; f.pl. aceleaşi; GEN $\equiv \mathrm{DAT}$ : m.sg. aceluiaşi; f.sg. aceleiași; m.pl. acelorași; f.pl. acelorași) following the pattern of acela 'that'. It is the functional equivalent of the descendants of Lat. *metipse transmitted to the other Romance languages, but not to Romanian. Insuşi lexicalized and later grammaticalized as an intensifier/focal particle with a full-fledged inflectional paradigm, marking person, number, gender and case oppositions. At the same time, ins gradually lost its function as a focal particle for that of a pronominal substitute (see $\$ 2.3$ below), while the bound focal particle $-s, i$ was gradually eliminated and fossilized in the structure of acelaşi and insuşi (see also Vasilescu, 2015). The most frequently used term of the paradigm was insuşi (person 3, singular, masculine, NOM $\equiv \mathrm{ACC}$ ), which might be the immediate consequence of its complex inflection (the lack of agreement occurring both in old and present-day Romanian), but it might also indicate the stages of its grammaticalization, as hypothesized below:

I. ins (focal particle inherited from Latin)

II. $\quad-s i$ (bound focal particle developed in old Romanian)

III. insuşi (newly created focal particle in old Romanian)

IV. lexicalization of the focalizer însuşi

V. the development of an inflectional paradigm of the focalizer insuşi by analogy with the dative forms of the personal/reflexive pronoun (ins $+m i / t i / n e / v a ̆)$

VI. grammaticalization of the focalizer insuşi with a full-fledged pronominal paradigm

An early categorial specialization of the forms descending from Lat. ipse is to be noticed: $i n s_{1}$ and the other forms having it as a lexical base (însul, nusul, dînsul, adins, însuşi) displayed pronominal features allowing independent, modifier or adverbial uses; ins/îns $s_{2}$ was a generic noun with several synonyms (ins 'guy', om 'man', persoană 'person', individ 'individual, fellow'); îns(ă) was a textual demonstrative deictic with conjunction-like functions in old Romanian, only later fully grammaticalized as adversative conjunction (see $\$ 2.2-2.3$ below).

The inflectional paradigms were regular. $\hat{I n} s_{1}$ was inflected for gender and number via desinences and phonetic changes in the root: m.sg. îns $\varnothing$, f.sg. însă, m.pl. înşi, f.pl. înse. Inns 2 was inflected like motional nouns, shared gender and number desinences with $\hat{\imath} s_{1}$ (m.sg. $\hat{\imath} /$ ins $\emptyset$, f.sg. $\hat{\imath} /$ ins $\breve{a}, \mathrm{~m} . \mathrm{pl}$. inşi, f.pl. inse) and showed initial vowel fluctuation for the $\operatorname{singular}(\hat{\imath} / i)$, later fixed as $i$, which formally differentiated 
the pronoun and the noun. Insuşi had the most complex inflectional paradigm, which seemed complete by the end of the period: the desinences and phonetic changes on the first component (m.sg. insu/f.sg. insă $/ \mathrm{m}$.pl. insşi/f.pl. inse) marked gender and number oppositions, while the suppletive forms of the second component (pers. $1 \mathrm{mi} /$ pers. 2 ți/pers. 3 și/pers. 4 ne/pers. $5 \mathrm{vă} /$ pers. 6 și) marked the person-number oppositions (for more examples, see DA, s.v.; Stan, 2013, p. 143; Vasilescu, 2016b, p. 388-391). Insul, nusul, dinsul marked gender and number oppositions through the forms of the definite article in their structure and the consonant alternation $s / s$, for the masculine singular/plural (m.sg. însul, f.sg. însa, m.pl. înşii, f.pl. însele; m.sg. nusul, f.sg. nusa, m.pl. nuşii, f.pl. nusele; m.sg. dînsul, f.sg. dînsa, m.pl. dînşii, f.pl. dinsele). In the beginning, adins displayed the inflection of ins in its structure, but it later developed into an invariable adverb. Initially a textual demonstrative deictic, ins( $\breve{a})$ had both a masculine form (ins) and a feminine form (însă) in old Romanian (DA, s.v.). The grammaticalization of the feminine form (not the masculine one) as an adversative conjunction seems consistent with a systemic feature of Romanian. It is exactly the feminine form which was selected for other textual deictics with "neutral" function: the demonstratives a (cea)sta, ace (e)a, ceea ce (9), the neutral pronominal clitic $o$ (10), the indefinite pronouns una, alta (11), the numerals a doua, a treia pragmaticalized as discourse markers (12) (see Pană Dindelegan, 2016b; 2016a, Anexe online, \$11.5).

a. pentru aceasta încă pohtesc carte

for this.F.SG still wish.PRES.1sG letter

dela impăratul (Dî.1600, XXXIII)

from emperor.DEF.M.SG

'for this reason I'm still waiting for a letter from the emperor'

b. Acea ne rugăm

that.F.SG CL.REFL.DAT $\equiv$ ACC.1PL pray.PRES.1PL

domnilor-voastre

(Dî.1595, CII)

highness.DEF.DAT.F.PL =your.F.PL

'that is what we are asking you'

$\begin{array}{lll}\text { c. ceaea ce zice (cIst.1700-50,33 } & \text { ) }\end{array}$

that.F.SG what say.PRES.3SG

'what he says'

(10) Ascultăa $\quad s \breve{a} \quad$ o $\quad s t i i \quad c \breve{a} n u$

listen.IMP.2SG SA $\breve{A U B J}_{\text {SUB }}$ CL.ACC.F.SG know.SUBJ.2sG that not

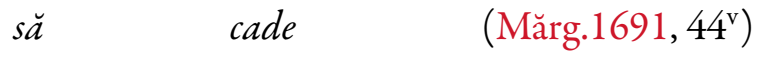

CL.IMPERS fall.PRES.3SG

'Listen, you should know that one should not do such a thing'

(11) și una și alta să dovedeaşte (CIst.1700-50, 58 $\left.8^{\mathrm{r}}\right)$

and one.F.SG and another.F.SG CL.IMPERS prove.PRES.3SG

'both one and the other are proven'

(12) Intăi, credința cea direaptă; a doa, nedeajdea;

first faith.DEF.F.SG CEL.F.SG right.F.SG A.F.SG second.DEF.F.SG hope.DEF.F.SG

a treia, liubovul cătră Dumnezeu (VRc.1645, $2^{\mathrm{v}}$ )

A.F.SG third.DEF.F.SG love.DEF.M.SG towards God

'First, the right faith; second, hope; third, love of God'

\subsection{Preservation of usages}

The corpus analysis indicates that the following usages of ipse in Latin have been preserved in old Romanian: independent focalizer (13), adjectival pre- $(14 a-b)$ or postposed focalizer $(14 c-d)$, or adverbial focalizer (15); reflexive pronoun (16); reciprocal pronoun (17); textual deictic (18). 
(13)

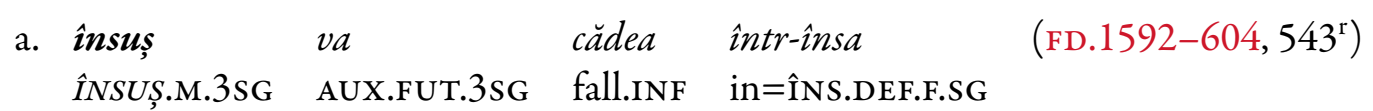
'he himself will fall in it'

b. insă să-l invăț $\quad$ (Sind.1703,79 $)$

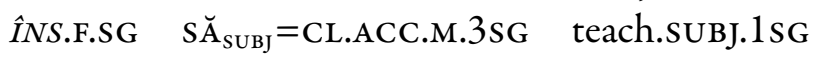
'to teach him myself'

c. fratele acestuia murit și numai brother.DEF.M.sG this.one.gEN.M.SG AUX.PERF.3SG die.PPLE and only insuşi au rămas (PO.1582,157)

INNSUSI.M.3SG AUX.PERF.3SG remain.PPLE 'his brother died and only he survived/and he remained alone'
a. ca ins trupul lui (CPr.1566-7, 430)

like $\hat{I N S . M . S G}$ body.DEF.M.SG his 'like his own body'

b. numai inșişi ucenicii Lui $\left(\mathrm{NT} .1648,112^{\mathrm{v}}\right)$ only îNSUȘI.M.3PL apprentice.DEF.M.PL his 'only his apprentices themselves'

c. ei insuşi (CPr.1566-7, 539) they îNSUŞI.M.3PL 'they themselves'

d. trupure inse (DPar.1683, III/130 $)$ body.N.PL $\hat{I N S . F . P L ~}$ 'the bodies themselves'

(15) $s \breve{a}$ trage CL.REFL.ACC.3SG originate.PRES.3SG ÎNSUŞI.M.3SG 'he himself comes from'
a. insuși-l
intrebaț
$\left(\right.$ Ст.1560-2, 206 $\left.{ }^{\mathrm{r}}\right)$
INNSUŞI.M. $3 \mathrm{PL}=\mathrm{CL} . \mathrm{ACC} .3 \mathrm{SG}$ ask.PRES.2PL
'You should ask him yourselves'

$\begin{array}{lllll}\text { b. însuş } & \text { au } & \text { izbăvit } & \text { pre } & \hat{i n s ̧ ̧ ~} \\ \text { ÎNSUȘI.M.3SG } & \text { AUX.PERF.3SG } & \text { save.PPLE } & \text { DOM } & \hat{I N S ̧ . M . S G ~}\end{array}$ 'he saved himself'
a. $s \breve{a}$ se
$e i$
S $\breve{A}_{\text {SUBJ }}$
choose UBJ.3PL
they.M
aleagă
CL.
adinş ei
(CPr.1566-7, 73)
ADINS they.ACC
'to choose among them'
b. ziseră adins eiş $\left(\mathrm{CC}^{1} .1567-8,29^{\mathrm{v}}\right)$ say.PS.3PL ADINS themș,
'they said to each other'

(18) Fiiul omenesc mearge-va pre zisă son.DEF.M.SG human go.INF=AUX.FUT.3SG DOM say.PPLE.F.SG

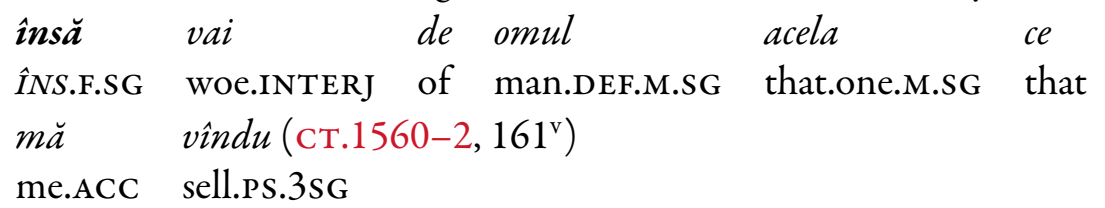

'Man's Son will trust your word, but woe to the one who betrayed me' 


\subsubsection{Focalizer}

The high frequency of the focalizer ins(uşi) seems to correlate with the content of the text and the persuasive function it has. On the one hand, focalizers were frequently used in religious texts to highlight unexpected/unpredictable actors and events and to impose them into the public consciousness. On the other hand, in legal texts they were used to emphatically assert the propositional content. In both cases, the speaker/writer takes stance with respect to the textual content and projects a rhetorical-persuasive attitude. In all the other textual genres the occurrence of $\hat{i n s}(u s i)$ is sporadic.

As an independent focalizer in old Romanian, insuşi might be equally interpreted as the focalizer of an empty category (însuşi pro/pro însuşi; însuşi ele însuşi) (Stan, 2013, p. 143) and a pro-form (for ins as a pronominal substitute, see $\$ 2.3$ below) intensified by the bound focal particle $-s i$. Evolutions in modern Romanian seem to support the latter interpretation: on the one hand, ins lost its use as a pronominal substitute, on the other hand $-s, i$ lost its function as a bound focal particle, while the newly created compound insuşi lexicalized as focalizer in the position of an external modifier of the $\mathrm{D}$ (eterminer) $\mathrm{P}$ (hrase).

In old Romanian, the use of insuşi as an adjectival focalizer was more frequent than its use as an independent focalizer (Vasilescu, 2015, p. 341). It combined with [+/- human] nouns and pronouns (see example (14) above). Its ante-position to the (pro)noun was considered an imitation of the Slavonic syntax of the original texts translated into Romanian (Stan, 2013, p. 60-61). Nevertheless, an internal explanation is not to be excluded taking into account the free word order in old Romanian, both in the sentence and inside the DP (see also the position of the adjective, the demonstrative and possessive determiners to the noun).

As an adverbial focalizer, însuşi frequently meant singur 'alone'. In Romanian, this meaning has been considered the reflex of the two meanings of samŭ in Slavonic: insuşi as intensifier (Engl. 'itself') and singur (Engl. 'alone') (see, among others, DA, s.v.; Stan, 2013, p. 61). Actually, what the texts in the corpus show is that ins(uşi) was a floating focalizer sharing the free word order with many other sentence constituents in old Romanian, and that it had various contextual meanings (see $\$ 2.4$ below), not only that of "singur" (Engl. 'alone'). Consequently, I suggest an alternative interpretation, adopting the concept of convergence, proposed by Hickey (2010, p. 19): the floating intensifier însuşi generated several contextual meanings, the strongest and most frequent one being 'alone' due to its convergence with the Slavonic samú. Insuşi meant 'itself, himself, not someone else' and contextually developed the meaning 'itself, himself, not someone else, hence alone'.

\subsubsection{Reflexive pronoun}

The reflexive use of ins (uşi) is consistent with the cross-linguistic data. From a typological perspective, languages display differences in expressing the reflexive and the intensification meanings (Gast \& Siemund, 2006): in what might be called the "syncretic language type", the reflexive and the intensifier have the same form (in English, for example); in what might be called "the non-syncretic language type", the reflexive and the intensifier have different forms (in German, the Romance languages, the Slavic languages, among others). Latin pertained to the non-syncretic type, although in late Latin ipse was sometimes used instead of a reflexive pronoun. This use was transmitted to old Romanian, where the stressed reflexive pronoun, the (focalized) personal pronoun and the intensifier însuşi (sine $\equiv$ elu $\equiv$ eluşi $\equiv$ insuşi, Engl. 'self' $\equiv$ 'him' $\equiv$ 'himșı' $\equiv$ 'himself') were functionally equivalent in some contexts, as exemplified in (19e-f) below.
a. Iisus Hristos arată
Jesus Christ show.PREs.3sG 'Jesus Christ shows himself here'
b. Pre elu se
DOM him CL.REFL.ACC.3SG
'he will lose himself'

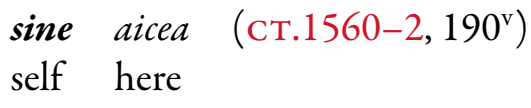
$v a$
AUX.FUt.3sg lose.INF
(Ст.1560-2, 137 $)$
piiarde

(C)




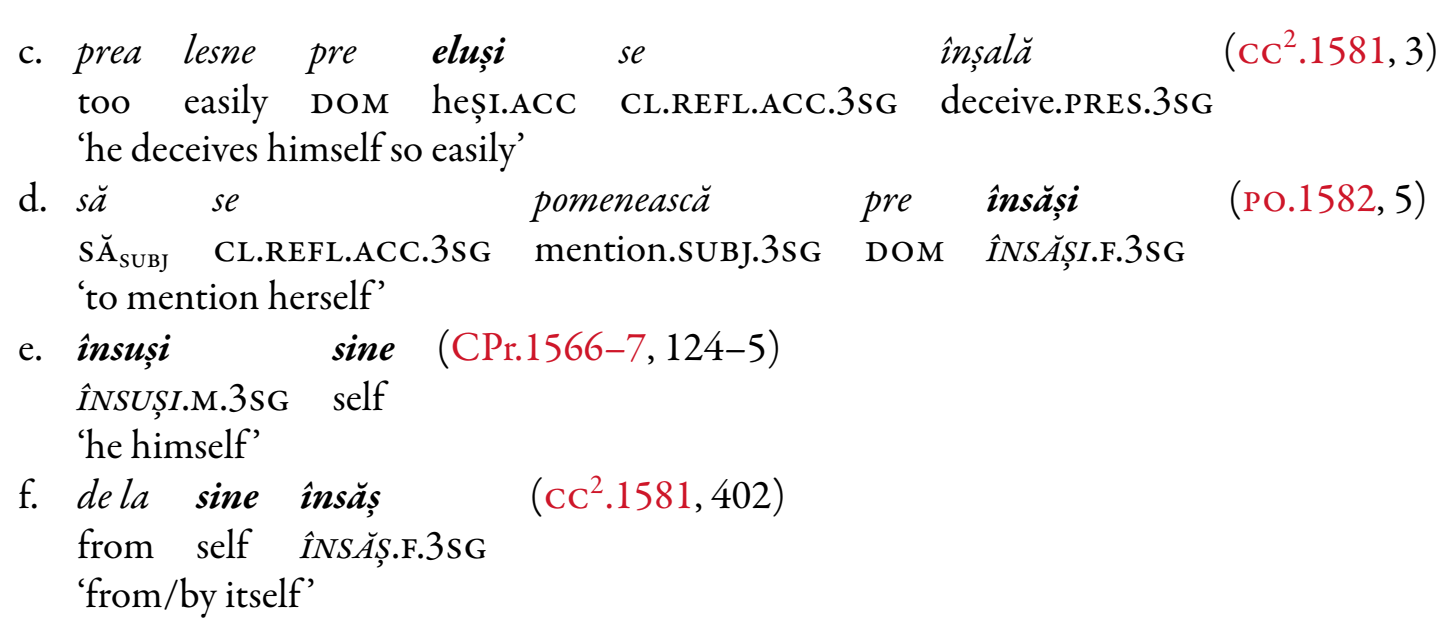

\subsubsection{Reciprocal pronoun}

In structures with semantically symmetrical predications, old Romanian presented several strategies to express the reciprocal meaning, directly linked to the Latin ones (details in Vasilescu, 2016a, p. 216-222). One such strategy involved a plural subject and a reciprocity prepositional phrase (intre ei 'among them'), as in (20a). The pattern underlied the structure ad + ins (adins), where the reciprocal meaning paralleled the emphatic one (20b). By the middle of the $17^{\text {th }} \mathrm{c}$. the reciprocal meaning faded out (DA, s.v.) and adins functioned exclusively as a focalizer (20c) that moved outside the DP and entered various adverbial phrases (Engl. 'purposely', 'deliberately', 'with intent') (20d). For a detailed analysis of adins in old Romanian, see Zamfir \& Uță Bărbulescu (2016).
a. ei inde ei tocmindu-s $\breve{a}$ (CII 1705, 86) they among they.ACC bargain.GER=CL.REFL.ACC.3PL 'bargaining among them'
b. voi adinsu voişi 'you among yourselves' you.2PL ADINSU youșI.2PL
(DA, s.v.)
c. adins eluşi aşa poruncește (DA, s.v.) ADINS heși so order.PRES.3SG 'he himself orders that'
d. (mai) (cu) deadins(ul), in deadins, (mai) (cu)dinadins(ul), cu tot dinadinsul, înadins, intr(u)-adins (DA, s.v.) 'on purpose'

\subsubsection{Between textual deictic and adversative conjunction}

As a demonstrative pronoun, the Latin ipse allowed a propositional focalizer usage. Hence, it is reasonable to assume that some structures in old Romanian continued this use, as in (18) above, where ins( $\breve{a})$ resumes a previous predication to generate, via conventional implicatures, a contrast with the newly introduced predication $\left(\right.$ sentence $_{1} \wedge \hat{i n s} \breve{a}_{\text {textual deictic }} \wedge$ sentence $_{2}$ ). Insă could show anywhere in the sentence (at the beginning, in the middle, at the end). The occurrence of the feminine form [see 2.1 above] of the textual deictic in contexts where the adjacent sentences stood in an adversative logical relationship triggered its grammaticalization as an adversative conjunction that joined the series dar, iar, ci (cf. DA, s.v.). Unlike the other conjunctions' obligatory front position, the position of the conjunction $i n s a ̆$ is still free in presentday Romanian and reminds of its former function as textual deictic.

\subsection{New usages}

Compared to Latin, the uses of $\hat{\imath} n$ s(ul)/innsuşi as a pro-form and $\hat{\imath} n s / i n s$ as a noun were an innovation of old Romanian. 


\subsubsection{Personal pronoun}

A DP/sentence focalizer in Latin, ipse developed in old Romanian along two complementary paths: a newly created form însuşi $(<\hat{i n s}+-s i$ ) was undergoing a lexicalization and grammaticalization process as intensifier (see $\$ 2.2 .1$ above), while the direct descendant of ipse, Rom. ins, was gradually losing its focal function developing into a pronominal substitute, a synonym of the $3^{\text {rd }}$ person singular personal pronoun $($ el/ea $-\hat{\imath} n s u l)$. With this function, it only accidentally occurred as the argument of a verb (21), but it was highly frequent in $\mathrm{P}$ (repositional) $\mathrm{P}$ (hrases) as the complement of the head preposition, realized in three phonologically and lexically constrained variants: following prepositions ending in the consonant cluster ntr (într-îns (ul) 'in it' / dintr-îns (ul) 'out of it' / printr-îns (ul) 'through it', etc.), as in (22a-b); following the preposition de (dins(ul) < de +ins(ul) 'of/about it'), as in (22c); following the preposition cu (cu nus(ul) $<c u+\hat{i n s}(u l)$ ' with it'), as in (22d-e). This is what I herein call differential prepositional object marking: a dedicated pronominal form (insul) occurred in PPs, distinct from the ones which regularly occurred as arguments of verbs ( $e l$ 'he', $e a$ 'she').

$\begin{array}{llll}a & \text { veacilor } & \text { munci } & \hat{i n s s i ~} \\ \text { AL.F.SG } & \text { century.DEF.GEN.M.PL } & \text { labour.PL } & \hat{I N S S . M . P L}\end{array}$

ni le tragem $\left(\mathrm{CC}^{2} .1581,315\right)$

CL.DAT.1 PL CL.ACC.F.3PL carry.with.us.PRES.1PL

'we carry with us labours as old as centuries'
a. Beați toți dentr-îns
drink.IMP.2PL all.M.PL from=îNS.M.SG
(CCat.1560, $11^{\mathrm{v}}$ )
'drink of it, all of you'
b. Domnul minie-se
Lord.DEF get.angry.PS.3SG=CL.REFL.ACC.3SG towards=îNS.F.SG
'God gets angry with her'
$\begin{array}{lll}\text { c. Domnul auzi-mă-va } & \text { cind voiu } \\ \text { Lord.DEF } & \text { hear.INF=CL.ACC.1 SG=AUX.FUT.3SG } & \text { when } \\ \text { AUX.FUT.1sG }\end{array}$
stăga cătră Dănsul $\quad\left(\mathrm{PB} \sim 1651,5^{\mathrm{v}}\right)$
call.out.INF towards DîNSUL.M.SG
'God will hear me when I call him out'

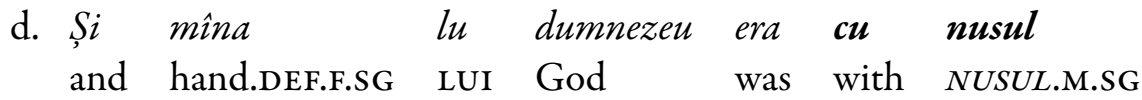
'and God's hand was with him'
e. ce grăiești cu nusa? $\quad\left(\mathrm{CC}^{1} .1567-8,22^{\mathrm{r}}\right)$
what speak.PRES.2SG with NUSA.F.SG
'what are you talking with her?'

This evolution was strongly influenced by the emergence in Romanian of the bound focal particle $-s i$ adjoined to words from various morphological classes (see $\$ 2.1$ above). In a pronominal system with parallel strong and clitic forms, it is highly probable that ins and -și were both reflexes of the Lat. ipse, the former, the strong form, and the latter its clitic counterpart. Initially, the two forms probably functioned as independent strong focalizer and clitic focalizer, respectively; later, after -și fossilized in the newly created lexemes însuşi 'itself/himself' and acelaşi 'the same', the clitic might have disappeared and been compensated by insuşi, which thus enhanced its position in the system of Romanian. This process allowed ins (ul) to change its focal particle function into a mere substitute, an alternative term to $\mathrm{el}$ 'he' or ea 'she', differentially selected: insul in PPs, el/ea in verb argument positions. Nevertheless, the rule of differential prepositional object marking did not apply strictly. 


\subsubsection{Generic noun}

The nominal use of ins/ins (om, persoană, individ, Engl. 'guy', 'man', 'person', 'individual', 'fellow') was an innovation of old Romanian compared to Latin. This use was attested since the earliest texts in the $16^{\text {th }} \mathrm{c}$. throughout the whole period. See examples in $(2 a-b)$ above. The masculine form was the most frequent one, and it occurred in the context of definite or indefinite quantifiers. The form has been connected to the Albanian vete (DA, s.v.).

\subsection{Polisemy}

The focal particle insuşi developed various secondary meanings through contextually generated conventional implicatures. Basically, it functioned as a purely focal particle "exactly X" (23a), but it also acquired the meaning of a contrastive focal particle "X, not $Y$ " (23b), a cumulative focal particle "even X" (23c), a focal particle of uniqueness ("only X, nobody else") (23d), a focal particle of non-causation contrasted to similar events controlled by an external agent ("by itself, nobody else caused the action") (23e), metalinguistic focal particle, synonym to "in itself" (23f), a synonym of the prefix-like segment (Rom. "prefixoid") auto 'self' (23g).

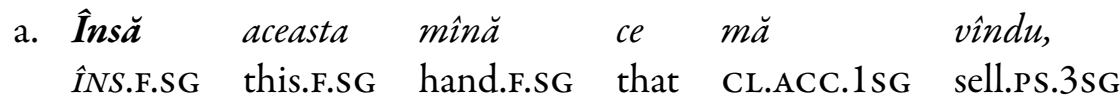

cu noi iaste la masă (Ст.1560-2,171 $1^{\mathrm{v}}$ )

with us is at table

'the very same hand that has sold me is with us at this table'

b. vedeți mînile meale și picioarele meale

see.IMP.2PL hand.DEF.F.PL my.F.PL and foot.DEF.NEUT.PL my.FEM.PL

că insumi eu sint (Ст.1560-2, 179v)

that INSUMI.M.1sG I am

'Look at my hands and my feet and see that it is me!'

c. cu credința însăş̧ sara sămînță

with faith.DEF.F.SG îNS $\breve{S ̧ . F .3 S G ~ e v e n i n g . D E F ~ s e e d ~}$

luo $\quad\left(\mathrm{CC}^{1} .1567-8,87^{\mathrm{r}}\right)$

take.PS.3sG

'She herself faithfully took that seed in the evening'

d. doamne, nu grijeşti că sora mea

Lord.voc not care.PREs.2sG that sister.DEF.F.SG my.F.SG

läsatu-m-au

însămi

let.PPLE $=$ CL.ACC. $1 \mathrm{SG}=\mathrm{AUX} \cdot \mathrm{PERF} \cdot 3 \mathrm{SG} \quad \hat{I N S S ̆ M I} \cdot \mathrm{F} \cdot 1 \mathrm{SG}$

să slujesc? $\quad\left(\mathrm{CC}^{1} .1567-8,234^{\mathrm{v}}\right)$

S $\breve{A}_{\text {SUBJ }} \quad$ serve.SUBJ.1sG

'God, you don't care that my sister left me all alone to serve?'

e. Ușile, iale inseşi sănchiserăa (apud DA, s.v.)

door.DEF.F.PL they.F.PL ÎNSEŞI.F.3PL CL.REFL.ACC.3PL=shut.PS.3PL

'the doors closed by themselves'

f. Țara Ardealului nu este $o$ țară

country.DEF Ardeal.DEF.GEN.F.SG not is a.F.SG country.F.SG

insuşi, ci "Ardealul” este și se cheamă

INSSUŞI.M.3SG but Ardeal.DEF.M.SG is and $\mathrm{SE}_{\text {IMPERS }}$ call.PRES.3SG

mijlocul țării (apud DA, s.v.)

middle.DEF.NEUT.SG country.GEN.F.SG

"The country of Ardeal is not a country properly, but "Ardeal" is and is called the middle of the country' 

g. însuți-văzătoriu,
ÎNSUȚI.M.SG=voy
insuți-făcătoriu,
insuşi-stăpinitor
(apud DA, s.v.)
'self-voyant', 'self-maker', 'self-ruler'

All the usages share the focal function; the prototype generates particular meaning effects, as discourse projections of various implicit communicative intentions.

\subsection{Contextual synonyms}

From the earliest texts preserved in Romanian, ins(uşi) had various synonyms: chiar 'clearly, right' < Lat. clarus (24a), numai 'only' < nu mai / Lat. non magis (24b), singur 'alone' < Lat. singulus (24c), tocmai 'exactly' < Slav. tüküma (24d), unul 'one' < Lat. unus (24e).
a. din chiar pornirea sa (Prav.1646, 214)
from right will.DEF.F.SG his.F.SG
'of his own will'
b. aceastea numai Iisus Hristos [...] au dobindit ( $\left.\mathrm{CC}^{1} .1567-8,114^{\mathrm{r}}\right)$
this.F.PL only Jesus Christ AUX.PERF.3sg attain.PPLE
'only Jesus Christ attained that'
c. indrăgeaște priiatnicul tău, ca tine
love.IMP.2sG friend.DEF.M.sG your.M.sG like you.ACC.2sG
singur (CPr.1566-7, 406)
alone
'love your friend like yourself'
d. sufletele tocma care-s ale lor (Ev.1642,60)
soul.DEF.PL indeed that $=$ are AL.FEM.PL their.GEN
'the souls which belong to them, indeed'
e. nimea nu e bun, numai dumnezeu unul $\left(\mathrm{CC}^{1} .1567-8,91^{\mathrm{r}}\right)$
nobody not is good only God.M.sG one.DEF.M.SG
'nobody is good, but God alone'

Cumulative, redundant uses were frequent (25); several idioms functioned as intensifiers due to their concrete meanings referring to self through a pars-pro-toto relationship (26a-b).
a. elu numai însuşi
he only îNSUȘI.M.3SG alone.M.SG
'him and only him'

b. tocma și pre sine însuş

indeed also DOM self îNSUȘ.M.3sG

'he himself included, indeed'
c. el unul singur \{iaste\} imblătoriu întrunoi $\left(\mathrm{CC}^{1} .1567-8,41^{\mathrm{r}}\right)$
he one.DEF.M.sG alone.M.SG is walking among us
'he himself and no one else is walking among us'
a. eu [...] insum,
cu mena
I INSUMI.M.1sG with hand.DEF.F.SG my.F.SG
'I myself, with my own hand'
b. El însuşs cu limba sa
he îNSUŞI.M.3sG with tongue.DEF.F.SG his.F.SG
'He himself, with his own mouth'

Overall, in old Romanian însuşi was more frequent than any of its synonyms (a quantitative approach in Vasilescu, 2016b, p. 392). 


\section{From old Romanian to modern Romanian}

In the passage from old Romanian to modern Romanian, the number of lexical units, formal variants and systemic syncretisms decreased as forms became ever more functionally specialized and register-marked. Present-day Romanian preserved însuşi, însă, dînsul, ins, adins, într-/printr-/dintr-/etc.-însul, but lost îns $s_{1}$, $\hat{i n s} s_{2}$, and nusul, and shows 1:1 form-function correlations: însuş - focal particle; însă - conjunction; insul, dînsul - pronouns; ins - noun; adins - adverb (in adverbial idioms). Combinatorial restrictions changed compared to old Romanian and each lexical unit originating in Lat. ipse has a particular register distribution in present-day Romanian.

\subsection{The focal particle însuşi}

In the first half of the $20^{\text {th }} \mathrm{c}$. the independent use of insuşi (sometimes ambiguous between a pronominal and an adverbial reading) was still attested $(27 a-e)$, but it became ever rarer by the end of the century. At the same time, at the beginning of the $20^{\text {th }}$ c. insussi in its adjectival use frequently combined with [-animate] nouns (28a-i), but tended to be an external modifier of [+human] nouns/pronouns exclusively, even though the [-animate] context was not totally excluded (29). It has preserved some of the semantic values it had in old Romanian (see $\$ 2.4$ above) - contrastive focalizer, cumulative focalizer, focalizer of uniqueness (a detailed analysis in Zafiu, 2013) - , but lost the non-causative and metalinguistic focalizer value, replaced by singur ('alone', 'itself') and propriu-zis ('properly', 'in itself'), respectively; for the prefix-like value (Rom. "prefixoid") it was replaced by auto in present-day Romanian. Ever more frequently, it combines with the strong reflexive pronoun (sine) forming an intonational unit (30); in the clitic chain $[s e$... pe sine], pe sine disambiguates the anaphoric function of the reflexive clitic, and insuşi functions as a focal particle of the strong reflexive. The syntagms [personal pronoun + insuşi] tend to grammaticalize for the emphatic reflexive value (31). For the structural features and the use in presentday Romanian, see Vasilescu (2008, p. 218-222; 2013, p. 404-407); Zafiu (2013, p. 287-294).

a. $H B$ a venit insuşi

HB AUX.PERF.3SG come.PPLE ÎNSUŞI.M.3SG

in România [1935] (apud Iordan, 1947, 313)

in Romania

'HB came himself to Romania'

b. renunțăm de a vorbi

give.up.PRES.1PL DE $A_{\mathrm{INF}}$ speak.INF

inşine [1936] (apud Iordan, 1947, 313)

INSŞINE.M.1 PL

'we give up speaking ourselves'

c. despre una din călătoriile sale vorbește

about one.F of travel.DEF.F.PL his.F.PL speak.PRES.3SG

insuşi [1937] (apud Iordan, 1947,313)

ÎNSUŞI.M.3SG

'he himself speaks about one of his travels'

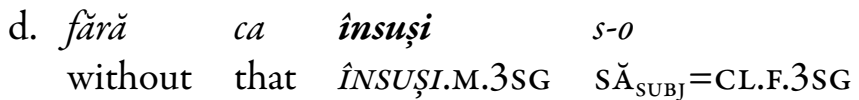

guste [1937] (apud Iordan, 1947, 313)

taste.SUBJ.3SG

'without tasting it himself'

e. marile spirite inşile

great.DEF.F.PL minds.NEUT.PL ÎNŞILE.M.3PL

[1937] (apud Iordan, 1947, 313)

'the great minds themselves' 
a. $\hat{I} n$ sînul însuşi al

al limbii

in bosom.DEF.M.SG ÎNSUŞI.M.3sG AL.M.SG language.DEF.GEN.F.SG

române

(Philippide, 1894, 35)

Romanian.GEN.F.SG

'right in Romanian'

b. se

\begin{tabular}{lll} 
se & \multicolumn{1}{l}{ schimbă } & uzul \\
CL.REFL.ACC.3sG & change.PRES.3SG & usage.DEF.NEUT.SG \\
insusi & (Philippide, 1894,42) &
\end{tabular}

ÎNSUŞI.M.3SG

'the usage itself is changing'

c. in insăşi limba

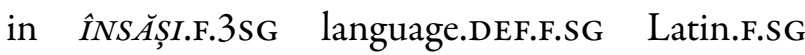

'even in Latin'

d. inseși sunetele (Iordan, 1947, 16)

INNEȘI.F.3PL Sound.DEF.NEUT.PL

'even the sounds'

e. pe a noastră însăşsi (Iordan, 1947, 17)

DOM AL.F.SG our.F.SG ÎNSĂșI.F.3SG

'even ours'

f. „coraş" insuși are, in popor,

"coraș" îNSUȘI.M.3sg has in people

sensul de „dispoziție, veselie” (Iordan, 1947,30)

meaning.DEF of mood joy

'«coraș» itself has, in its colloquial use, the meaning «mood, joy»'

g. Academia însăși cerea să

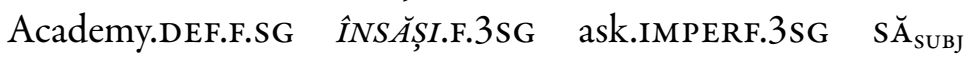

scriem -ia (Iordan, 1947,33)

write.SUBJ.1PL $-i a$

'The Academy itself recommeded the spelling with $-i a$ '

h. sintaxa oricărei limbi este, prin ea

syntax.DEF any.GEN.F.SG language.GEN.F.SG is through she

însuşi (sic!), mai bogată (Iordan, 1947,279)

INNSUŞI.M.3SG more rich.F.SG

'the syntax of any language is, in itself, richer'

i. prin și pentru ele înseși (Iordan, 1947, 279)

by and for them.F iNSEŞI.F.3PL

'by and for themselves'

(29) Brexitul arată ceva mai grav decît

Brexit.DEF.M.SG show.PRES.3SG something more serious than

Brexitul insuşi (EvZ)

Brexit.DEF.M.SG INNSUŞI.M.3sG

'The Brexit shows something more serious than the Brexit itself'

(30) un bărbat $s$-a căsătorit cu

a man CL.REFL.ACC.3SG=AUX.PERF.3SG marry.PPLE with

sine însuşi (zC)

self îNSUŞI.M.3sG

'a man got married to himself'

$\begin{array}{llll}\text { a. Iohanis, impiedicat } & \text { de el insuși } \\ \text { Iohannis obstruct.PPLE.M by he ÎNSUȘI.M.3sG }\end{array}$ 
'Iohannis, obstructed by himself'

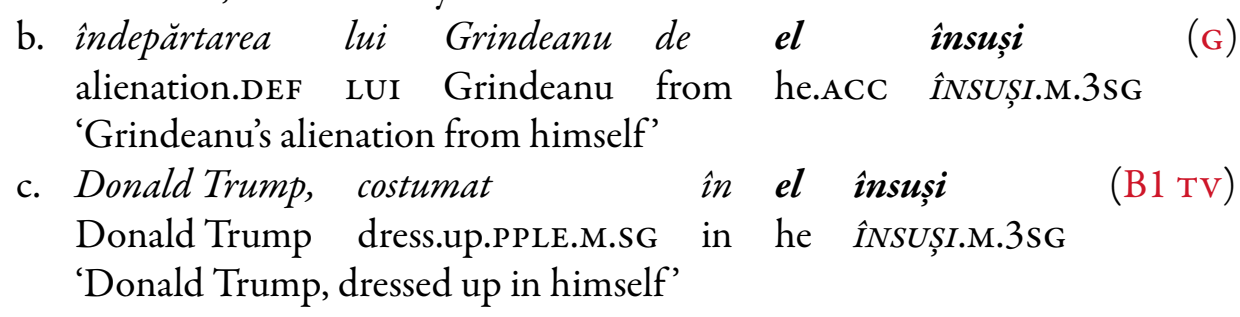

Insuşi is quasi-absent in non-standard Romanian, yet not excluded. In the subdialectal corpus ${ }^{1}$ investigated, there is only one occurrence (32).

(32) el i... nu prea $[\epsilon]$ se-ngrijea

he not really CL.REFL.3sG=take.care.IMPERF.3SG

pe el insuş personal (Moldova \& Bucovina, 230)

DOM he.ACC ÎNSUŞ.M.3SG personally

'he wasn't really taking care of himself'

There are several possible convergent explanations for these register differences. First, insuşi incorporates the conventional implicature "invalidation of expectations", which indicates an argumentative-persuasive stance of the speaker/writer in relation to the listener/reader, which might explain the occurrence of insuşi in argumentative-persuasive genres, but its absence in spoken non-standard Romanian texts, produced in various communication situations where both the interviewer and the respondents normally take a neutral stance. It seems that, both in old Romanian and in contemporary Romanian, însuşi is more than a focal particle: it is a stancetaking marker. This discursive function makes the difference to the synonyms of insuşi and explains register selections [see $\$ 2.5$ above, and examples (35)-(38) below]. Second, spoken varieties prefer either intonational focalization, as the propositional turn indicates (33), or the syntactic strategy of explicit opposition between terms (34).
a. Cerneala o
făceam
noi
(AD I, Vîlcea, 7)
ink.DEF.F.SG CL.F.3SG make.IMPERF.1PL we.NOM
'we used to make the ink ourselves'
$\begin{array}{llll}\text { b. Cărate } & \text { bucătille } & \text { de mine acolo } \\ \text { carry.PPLE.F.PL } & \text { piece.DEF.F.PL by me there }\end{array}$

la arina boierească (AD I, Tecuci, 25)

at yard.DEF.F.SG manorial.F.SG

'the pieces carried by me there at the boyard's yard'

c. Am auzit eu dela părinții mei (AD I, Roman, 30)

AUX.PERF.1sG hear.PPLE I from parent.DEF.M.PL my.M.PL

'I heard it myself from my parents'

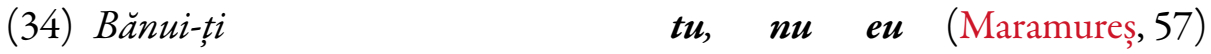

regret.IMP.2SG=CL.REFL.DAT.2SG you not I

'regret it yourself, not me'

Third, the complex inflexion of însuşi might explain the speakers' preferences for the synonym lexical focalizers chiar 'even', singur 'alone', unul 'one', cu ochii mei 'with my own eyes', especially in non-standard Romanian (35)-(38).

\footnotetext{
${ }^{1}$ The phonetic transcription of the texts used in examples was simplified and presented as literary transcription, considering that the phonetic features marked in the original transcript are irrelevant for the phenomena under discussion in this article.
} 
a. Eu chiar eu am născut

la unu noaptea (Muntenia, 242) I right I AUX.PERF.1sG give.birth.PPLE at one night.DEF 'I myself gave birth at one o'clock at night'

b. Chiar mie (Muntenia, 243) right me.DAT 'right to me'

c. Povestea chiar frati-su ei (Moldova \& Bucovina, 123) narrate.IMPERF.3SG right brother=her.M.SG her.GEN.F 'her own brother used to tell that story'
a. Atunci $o$
ieșit
ei
then AUX.PERF.3SG $\equiv \mathrm{PL}$ come.out.PPLE they.M alone.M.PL
'then they came out all alone'

b. El singur, să stie, ar face

he alone.M.sG SĂ $\breve{S U B J}_{\text {f }}$ know.SUBJ.3SG AUX.COND.3sg do.INF

ceva (GN, Bucovina, 31)

something

'if he knew, he himself would do something'

c. Am mers singuri și-am

AUX.PERF.1PL gO.PPLE alone.M.PL and=AUX.PERF.1PL

văzut (AD I, Basarabia, 41)

see.PPLE

'We went alone and we saw'
d. il taie el singur (Porţile de Fier, 198)
CL.ACC.M.3SG cut.PRES.3SG he alone.M.SG
'he cuts it all alone'
e. Eu singur vi l-oi
I alone.M.SG CL.DAT.2PL CL.ACC.M.SG=AUX.FUT.1SG
lega (GN, Maramureș, 88)

tie.INF

'I myself will tie it for you, all alone'

f. ea singură [...] bate (Dobrogea, 306)

she alone.F.SG beat.PREs.3sG

'she alone beats'

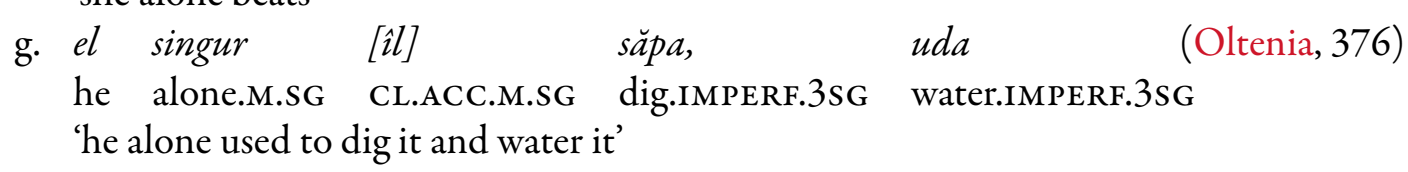

(37) a. Ca pe mine pe una (GN, Maramureș, 51)

like DOM me.ACC DOM one.F.SG

'like myself'
b. Eu una l-am omoritt (GN, Maramureș, 106)
I one.F.SG CL.ACC.M.3SG=AUX.PERF.1sG kill.PPLE 'I myself killed him'

(38) $i$-am

CL.ACC.M.3PL=AUX.PERF.1SG

văzut eu cu ochii

mei (AD I, Săcele, 43)

my.M.PL

'I saw them with my own eyes' 


\subsection{The adversative conjunction însă}

There are relatively clear-cut pragmatic differences among the adversative conjunctions in present-day Romanian: dar and însă (Engl. 'but') invalidate expectations; ci (Engl. 'but') induces corrections to and substitutions in the propositional content; iar (Engl. adversative 'and') marks the thematic contrast (Zafiu, 2005, p. 3-5). Insă, unlike dar, signals the argumentative stance of the speaker (probably what Spiță, 2003, p. 253 calls a "supplementary emphatic function"), preserving the meaning it inherited from its old Romanian etymon însă/însăşi (see DA, s.v. and $\$ 2.2 .4$ above).

Moreover, there is a register difference between dar and insă. Dar (and its regional synonyms da, numa, fără) is generally preferred in the non-standard uses, while insă is generally preferred in standard uses (Zafiu, 2005, p. 3, note 9). Nevertheless, însă occurs in non-standard uses too, more frequently in Oltenia, Muntenia, and Moldova (Teiuş, 1980, p. 119-120). It is noteworthy that the samples in the corpus (39) occur in the speech of partly educated informants who have/had frequent/long term contacts with out-groups. The tautological use (40) could indicate that speakers do not interpret însă as a marker of the adversative relationship between constituents, but rather as a textual deictic, emphatically resuming its antecedent.
a. in timpul liber însă/ se-ntreținea
in time.DEF free $\hat{I N S . F . S G ~ C L . R E F L .3 S G=s o c i a l i z e . I M P E R F .3 S G ~}$
cu noi (Moldova \& Bucovina, 251)
with us
'in his spare time he used to socialize with us'
b. îns ă două oale se punea
INNS.F.SG two.F pot.F.PL CL.IMPERS put.IMPERF.3SG
prima dată (Muntenia, 150)
first.F time.F
'but the first time, two pots were counted'
$\begin{array}{llllll}\text { c. } \begin{array}{l}\text { asistam } \\ \text { witness.IMPERF.1SG }\end{array} & \text { de } & \text { multe } & \text { ori } & \text { la } \ldots & \text { diferite } \\ & \text { many.F.PL } & \text { time.F.PL } & \text { at } & \text { various.F.PL }\end{array}$

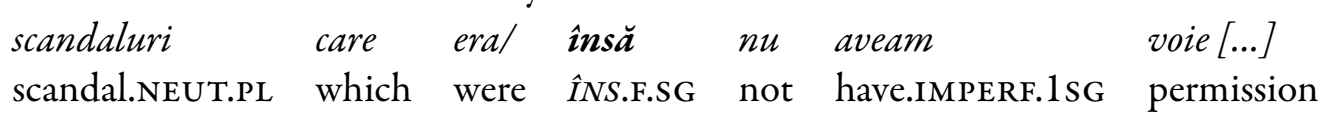
să $\quad m a ̆$... vîr (Moldova \& Bucovina, 118)
$\breve{S}_{\text {SUBJ }} \quad$ CL.REFL.ACC.1SG get.involved.SUBJ.1sG
'I used to witness many scandals, but I was not allowed to interfere'
d. Acum însă le zicem jupini și domni
now îNS.F.SG CL.DAT.3PL tell.PRES.1PL boss.PL and sir.PL
și rîd ei de noi (GN, Buzău, 226)
and mock.Pres.1PL they.M DE us
'but now we call them boss and sir and they mock us'
e. Asta insă nu $\hat{\imath} i \quad$ spunea lui
this.F.SG îNS.F.SG not CL.DAT.3sG tell.IMPERF.3sG LUI.DAT
frate-său (GN, Constanța, 369)
brother=his.M.SG
'but he would't tell that to his brother'
f. nu mai lucreazăl însă inainte bătrînii
not more work.PRES.3PL $\hat{I N S . F . S G}$ before old.people.DEF.M.PL
lucrau (Dobrogea, 247)
work.IMPERF.3PL
'they don't work anymore, but old people used to work before' 


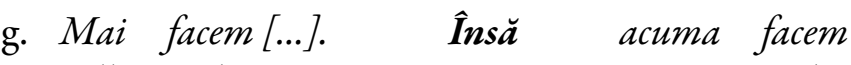

still make.PRES.1PL îNS.F.SG now make.PRES.1PL

cu prafuri (Oltenia, 1)

with powder.PL

'we still make. But nowadays we make it with powder ingredients'

(40)
a. dar însă noi trecusen
but îNS.F.SG we pass.PLUPERF.1PL
'but we had gone by'
b. dar însă nu dădea aşa randament
but îNS.F.SG not give.IMPERF.3sG such efficiency
'but it was not very efficient'
c. dar însă... [...] parcă... mă simt
but îNS.F.SG apparently CL.ACC.1sG feel.PREs.1sG
aşa (Moldova \& Bucovina, 1)
like.that
'but it seems I feel like that'

\subsection{The noun ins}

In present-day Romanian, the noun ins (Engl. 'guy', 'man', 'person', 'individual', 'fellow') occurs especially with its masculine plural form (inşi) combined with a quantifier, both in standard (41) and non-standard (42) uses. One peculiar occurrence, dinsul (otherwise a personal/politeness pronoun, see $\$ 3.4$ below) for ins, was spotted in a transcript (43), probably a formal confusion due to the infrequent use of the singular form ins.

a. La 113 inși ne aducea cîte o pî̀ne at 113 INS.M.PL CL.DAT.1PL bring.IMPERF.1PL each one.F bread.F 'they used to bring us one loaf of bread for each of the 113 persons'

b. Din maşina oprită au coborît cinci from car.DEF.F.SG stop.PPLE.F.SG AUX.PERF.3PL descend.PPLE five inși, toți cu cefe de bivol (MG) INS.M.PL all.M.PL with neck.F.PL of ox 'five guys with ox-like necks descended from the car which had stopped there'
c. chem in ajutorul meu pe acesti call.PRES.1sG in help.DEF.NEUT.SG my.M.SG DOM this.M.PL unul sau doi inşi (BF) one.DEF.M.PL or two.M INS.M.PL 'I call these one-two guys to help me'

a. Trei inși, beţi turtă, merg in patru labe (BZ) three INS.M.PL drink.PPLE.M.PL cake walk.PRES.3PL in four paw.PL 'three guys, as drunk as a fiddler, are crawling on the ground'
three four five INS.M.PL 'three-four-five guys'
a. treil patrul cinci inși (Muntenia, 151)
b. Am fostu vo cinci, șase inși (Tîrnave, 55) AUX.PERF.1PL be.PPLE around five six INS.M.PL 'We were around five-six guys'
c. doi inși (Bistrița-Năsăud, 75)
two INS.M.PL
'two guys'


d. Am fost vreo nouăzeci de inși (AD I, Transilvania, 51) AUX.PERF.1PL be.PPLE around ninety of INS.M.PL

'We were around ninety guys'

e. Atuncea facem o adunare/... șaptel optl zece

then make.PREs.1PL a reunion seven eight ten

inşi (Porțile de Fier, 174)

INS.M.PL

'then we gather seven-eight-ten guys'

f. eram doi inși (Bistrița-Năsăud, 75)

be.IMPERF.1PL two.M INS.M.PL

'we were two guys'

g. și-am fost doi inși (Moldova \& Bucovina, 21)

and=AUX.PERF.1PL be.PPLE tWo.M INS.M.PL

'and we were two guys'

h. mai mulți inși (Dobrogea, 499)

more many.M.PL INS.M.PL

'several guys'

(43) Apoi îş̧i fac oricare cîte ogaură înpămînt

then CL.REFL.DAT.3PL make.PRES.3PL anyone each ahole in ground

și tăt dînsu are cîte obotă în mînă[...] (Maramureș, 149)

and every DÎNSU has each a cudgel in hand

'then each dugs a hole in the ground and each one (each guy) has a cudgel in his hand'

The examples above indicate a register-induced difference in the meaning of ins: while in non-standard uses ins preserved the neutral connotation it had in old Romanian, in standard uses it mostly occurs in negatively connotated contexts, triggering a depreciative implication or projecting negative emotions.

\subsection{Dînsul-personal deictic, social deictic}

The lexical unit dinsul has been preserved in present-day spoken Romanian, both standard and nonstandard, but has undergone a process of functional differentiation.

In old Romanian it functioned as a pronominal substitute, initially after the preposition de, later it generalized in the $\mathrm{P}$ (repositional) $\mathrm{P}$ (hrase), and by the end of the period it functioned outside the PP (DLR, s.v.). Until the end of the $19^{\text {th }} \mathrm{c}$. and during the first decades of the $20^{\text {th }} \mathrm{c}$. it occurred as a personal deictic in standard Romanian (44), as well as in several regional varieties of Romanian (45af), more frequently in Moldavia and the North-East of Dobrogea (Rusu, 1984, p. 220-221). Dinsul and $e l$ had parallel uses $(45 \mathrm{~g})$. Notice example (45a), where dînsul occurs with an archaic form, without the incorporated definite article $(-u l)$.
a. Hîrtia
e răbdătoare,
căci pe dînsa
poți
paper.DEF.F.SG
is patient.F.SG
because on DÎNSUL.F.SG
can.PRES.2SG
scrie ce vrei
write.INF what want.PREs.2sG
(Budai-Deleanu, apud DLR, s.v.)
'Paper is patient, because you can write whatever you want on it'
b. Cucoana Caliopi a primit tustrele răvașele
Mrs. Caliopi AUX.PERF.3SG receive.PPLE all.three letter.DEF.F.PL
și a rămas incîntată
and AUX.PERF.3SG remain.PPLE delighted.F.SG
de dinsele (Negruzzi, apud DLR, s.v.)
by DîNSUL.F.PL

'Mrs. Caliopi received all three letters and was delighted with them' 
c. Inaintea tribunii, cu spatele spre

in.front.of stand.DEF.GEN.F.SG with back.DEF towards

dînsa (Caragiale, apud DLR, s.v.)

DÎNSUL.F.SG

'In front of the stand with their backs to it'

d. raporturile acestor manifestări intre

relationship.DEF.NEUT.PL this.GEN.PL manifestation.PL among

dinsele (Philippide, 1894, p. II)

DINNSUL.F.PL

'the mutual relationships of these manifestations'

a. Mai avea un singur fecior care mai era

still have.IMPERF.3sg one single son who still was

pelîngă dîns (HS, Moldova, 46)

near DîNS.M.SG

'he still had one son around'

b. Lupul a iessit cu oaia

wolf.DEF.M.SG AUX.PERF.3SG go.out.PPLE with sheep.DEF.F.SG

pe poartăll am fugit după dînsul

on gate AUX.PERF.1sG run.PPLE after DîNSUL.M.SG

cu cîini (Moldova \& Bucovina, 52)

with dog.PL

'The wolf went out the gate with the sheep, I ran after him with dogs'

c. Fac o casăl cu două camere [...] bătut

make.PREs.1sG a.F.SG house.F.SG with two.F room.F.PL fix.PPLE

tablăl sau carton/ pe dînsa (Moldova \& Bucovina, 49)

tin or cardboard on DîNSUL.F.SG

'I build a house with two rooms, I fixed tin or cardboard on it'

d. pînă cînd curățam eu cepurile

until when clean.IMPERF.1sG I spigot.DEF.NEUT.PL

dela dînsul (Bistrița-Năsăud, 81)

from DîNSUL.M.SG

'until I cleaned its spigots'

e. s-a-mburdat crucea

CL.REFL.ACC.3SG=AUX.PERF.3SG $=$ fall.PPLE cross.DEF

pe dinsul (GN, Oaş, 58)

on DîNSUL.M.SG

'the cross fell on him'

f. Intră-n casă străinul Și dă

enter.PRES.3SG=in house stranger.DEF.NOM.M.SG and give.PRES.3SG

mina cu dînsu (Maramureș, 40)

hand.DEF with DÎNSUL.M.SG

'the stranger enters the house and shakes hands with him'

g. Şi potrivim și-l culcăm lemnul să

and fix.PrEs.1PL and=CL.ACC.M.SG lean.PRES.1PL stick.DEF.M.SG S S $\breve{S U B J}_{\text {SUJ }}$

dăm $\quad c u \quad$ el citmaisus [...], să $\quad$ nu dăm $\quad c u$

hit.SUBJ.1PL with it as high S $\breve{A}_{\text {SUBJ }}$ not hit.SUBJ.1PL with

dînsul jos. Dacă dăm cu dînsu-njos,

DÎNSUL.M.SG low if hit.PRES.1PL with DÎNSUL.M.SG=downwards 


$\begin{array}{llllll}\text { atunci }[. . .] & \text { ne } & \text { ia } & \text { după } & \text { el (Oltenia, 162) } \\ \text { then } & \text { CL.ACC.1PL } & \text { pull.PRES.3SG } & \text { after } & \text { it } & \end{array}$

'And we fix and lean the stick to hit with it as high as we can, to avoid hitting with it at the lower part. If we hit with it at the lower part, then it pulls us after it'

After the second half of the $20^{\text {th }}$ c., dinsul began to function as a social deictic (politeness pronoun for the $3^{\text {rd }}$ person) in standard Romanian, shaping the grammatical system as a two person and four/three degrees of politeness: tu-dumneata-dumneavoastră-domnia voastră; el-dînsul-dumnealui-domnia lui; voi - dumneavoastră - domniile voastre; ei/ele - dînșii/dînsele - dumnealor - domniile lor (Vasilescu, 2008, p. 212-218; 2013, p. 401-402). Rarely, dinsul is used as a social deictic in non-standard varieties, especially in the Southern areas (46), by young persons constantly exposed to standard spoken and written Romanian in school and in the media.
a. Dînsul [judecătorul]
a fost
intrebat (Muntenia, 583)
DINNSUL.M.SG [the judge] AUX.PERF.3Sg be.PPLE ask.PPLE 'he was asked'
b. [tovarăşa invățătoare] $m-a$ comrade.DEF
teacher
CL.ACC
pus
pus să
SĂ $\breve{s U B J}$
povestesc
lecția $[\ldots]$
$M-a$
tell.sUBJ.1sG
lesson.DEF
$M-a$
pus
$s \breve{a} \quad z i c$
după ea
S $\breve{A}_{\text {SUBJ }}$ say.SUBJ.1sG after her
'[the teacher] asked me to tell the lesson. She asked me to repeat after her'
c. merge dinsul acolo cu noi (Oltenia, 365, 35 years old)
go.PRES.3SG DîNSUL.M.SG there with us
'he goes there with us'

The evolution of dinsul from a positional variant of the personal pronoun (after prepositions) to a social deictic (pronoun of politeness) might have gone through the following phases:

I. The phase of the semantic-cognitive opposition. After the form generalized in all the syntactic positions alternating with $e l$, the initial syntactic opposition (+/ - preposition) developed into a semanticcognitive opposition, i.e. cognitive distance to the referent (dînsul) vs. cognitive proximity to the referent $(e l)$, supported by similar systemic oppositions in old Romanian (demonstrative of proximity/ of remoteness - acesta/acela; proximal demonstrative of identity/remote demonstrative of identity acestaşi/acelaşi).

II. The phase of strategic politeness. The semantic-cognitive distance was converted into social distance/ hierarchy, and dinsul began to function as a social deictic, which marks deference in relation to a noninterlocutor human referent.

\subsection{Adins - adverb}

The adverb adins is used in regional varieties of modern Romanian (47), as well as in colloquial standard Romanian (48a-b); standard usage rather resorts to neologisms such as intenționat 'intentionally', special 'purposely', in mod expres 'expressly', deliberat 'deliberately'.

$$
\begin{aligned}
& \text { Și n-ar fi intr-adins (Făgăraș-Transilvania, 408) } \\
& \text { and not }=\text { AUX.COND.3sg be.INF in }=\text { ADINS } \\
& \text { 'and it wouldn't be on purpose' }
\end{aligned}
$$
a. Repere
in adins falsificate
(Roșu, 2012, 22)
landmark.F.PL in ADINS falsify.PPLE.F.PL
'landmarks deliberately falsified' 


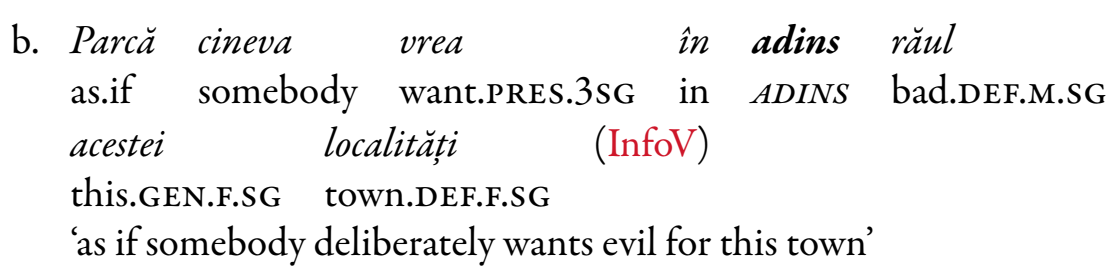

\subsection{Insul}

Insul, a syntactically and phonologically conditioned variant in present-day Romanian (after prepositions ending in $n t r$ ), was frequent until the beginning of the $20^{\text {th }}$ c. (49); it was progressively eliminated from standard Romanian, but still occurs in non-standard varieties (50). In standard Romanian the personal pronoun or the demonstrative is largely used (in el/acesta 'in it/in this one'; din el/din acesta 'from it/from this one'; printre ei/printre aceștia 'among them/among these ones', etc.).

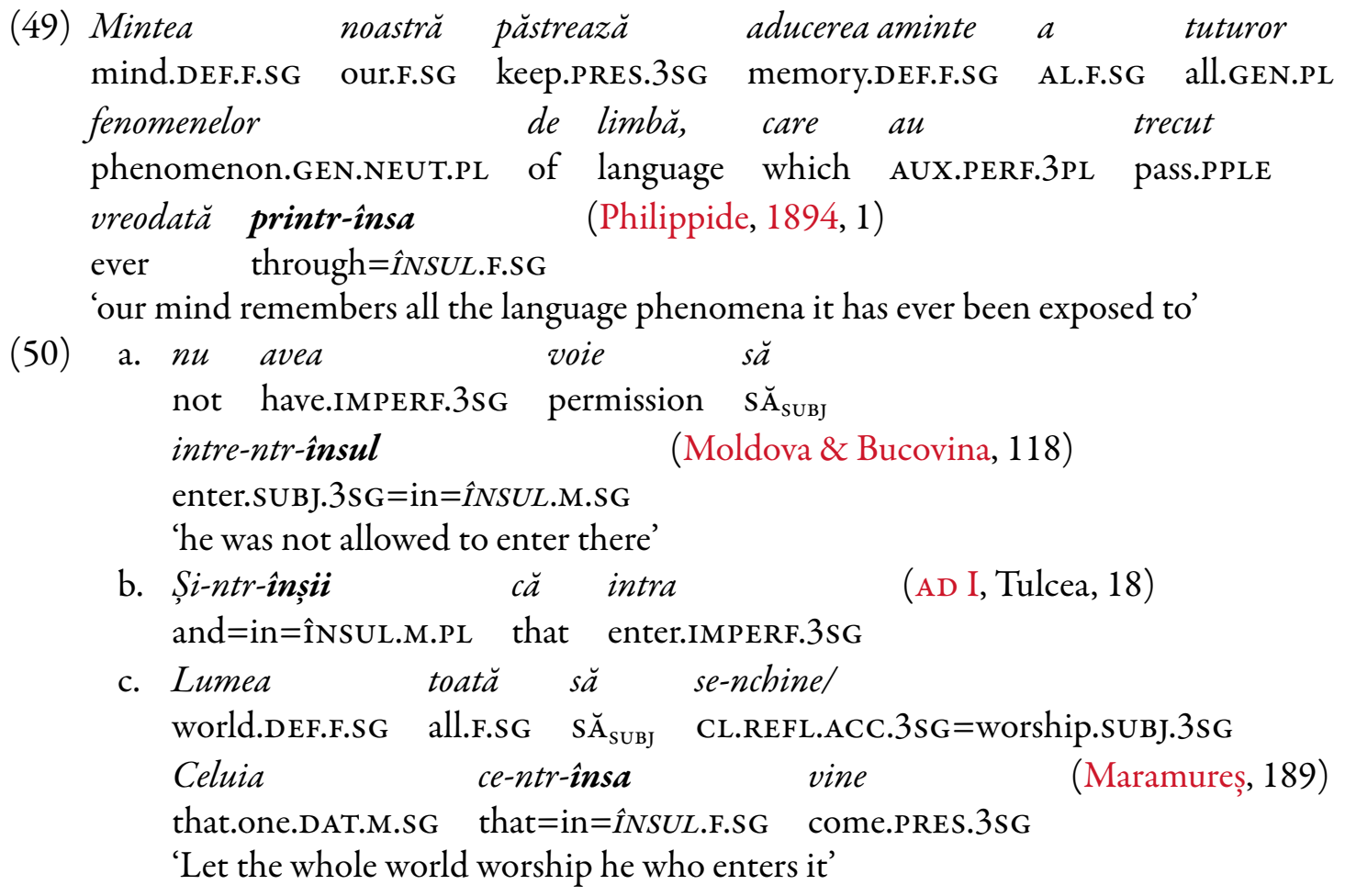

\section{Conclusions}

Romanian is the only Romance language that has preserved the formal descendant of the Lat. ipse and its uses (focal particle in the NP/PP, reflexive pronoun, reciprocal pronoun, and contrastive discourse deictic). Nevertheless, both the forms and the uses have slightly changed during the old and modern period.

The most significant phenomena in old Romanian (see $\$ 2$ above) compared to Latin are the proliferation of forms and the emergence of new functional correlations. In modern Romanian (see $\$ 3$ above) the most important changes concern the apparition of new lexical-grammatical syncretisms backed by new functional correlations and register preferences.

The following table synthetically presents the evolution of ipse from Latin to old Romanian and then to modern Romanian. 


\begin{tabular}{|c|c|c|}
\hline STAGE & FORMS & USAGES \\
\hline \multirow[t]{4}{*}{ Latin } & \multirow[t]{4}{*}{ *ipse } & 1. nominal and sentence intensifier (focal particle) \\
\hline & & 2. reflexive pronoun \\
\hline & & 3. reciprocal pronoun \\
\hline & & 4. demonstrative pronoun expressing contrast at discourse level \\
\hline \multirow[t]{10}{*}{ Old Romanian } & $\hat{\imath} \mathrm{ns}_{1}$ & 1. intensifier (focal particle) \\
\hline & & 2. reflexive pronoun/anaphor \\
\hline & $\hat{i n s}_{2} /$ ins & generic noun, convergent with Alb. vete \\
\hline & insul & phonologically conditioned pro-form $(<n t r+\hat{\imath} n s u l)$ \\
\hline & dînsul & syntactically conditioned pro-form (< de insul) \\
\hline & nusul & syntactically conditioned pro-form (<cu insul) \\
\hline & adins & 1. syntactically conditioned pro-form (< ad insu) \\
\hline & & 2. strategy to express the reciprocal meaning \\
\hline & insuşi & $\begin{array}{l}\text { 1a. pre- or postposed intensifier (focal particle) of a DP [+/- animate], } \\
\text { with various contextually acquired meanings: focalization, contrastive } \\
\text { focalization, cumulative focalization, singularity/uniqueness focaliza- } \\
\text { tion, focalization of non- causativity, metalinguistic focalization, a syn- } \\
\text { onym of the prefix-like particle auto; } \\
\text { lb. independent (free-standing) intensifier; } \\
\text { 1c. adverbial intensifier; } \\
\text { 2. reflexive pronoun }\end{array}$ \\
\hline & $\begin{array}{l}\text { (possible) } \\
-s ̦ i\end{array}$ & $\begin{array}{l}\text { bound intensifier attached to lexemes from various classes (pro-forms, } \\
\text { demonstratives, indefinites, numerals) }\end{array}$ \\
\hline \multirow[t]{6}{*}{$\begin{array}{l}\text { Contemporary } \\
\text { Romanian }\end{array}$} & & $\begin{array}{ll}\text { Standard Romanian } & \begin{array}{l}\text { Non-standard Romanian } \\
\text { (sub-dialectal Romanian) }\end{array}\end{array}$ \\
\hline & insuşi & 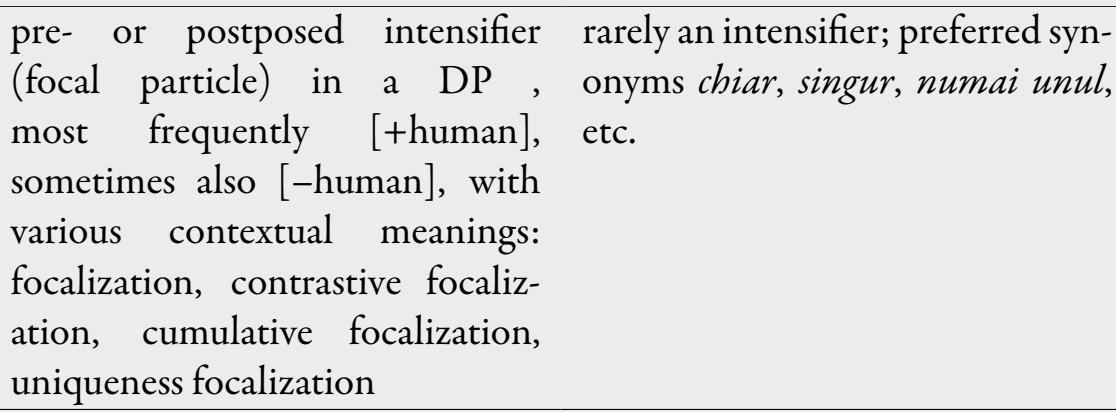 \\
\hline & ins & $\begin{array}{l}\text { generic noun used in negat- } \begin{array}{l}\text { generic noun, frequently used, } \\
\text { ive/disphoric contexts }\end{array} \\
\text { neutral context }\end{array}$ \\
\hline & $\hat{i n s a ̆ ~}$ & $\begin{array}{l}\text { conjunction, functionally distinct } \begin{array}{l}\text { conjunction, rarely used, espe- } \\
\text { from the others in the adversative } \\
\text { cially in redundant syntagms } \\
\text { series (dar, iar, ins } \breve{a}, c i)\end{array}\end{array}$ \\
\hline & dînsul & $\begin{array}{ll}\text { social deictic, expressing an inter- } & \text { pro-form, often expressing cognit- } \\
\text { mediate degree of politeness with } & \text { ive distance; a strong tendency } \\
\text { respect to the non-speaker/hearer } & \text { towards acquiring a social deictic } \\
\text { participant in the interaction } & \text { function }\end{array}$ \\
\hline & adins & $\begin{array}{l}\text { colloquial; standard Romanian sometimes used in adverbial } \\
\text { and high registers prefer its idioms } \\
\text { synonyms intentionat, special, in } \\
\text { modexpres, deliberat }\end{array}$ \\
\hline
\end{tabular}


The evolution of ipse from Latin to present-day Romanian illustrates a case of poligrammaticalization (Diessel, apud Zamfir \& Uță Bărbulescu, 2016, p. 420) and polymorphism (Sornicola, apud Zamfir \& Uță Bărbulescu, 2016, p. 420), which is not the only one in the evolution of Romanian (see also Dinică, 2017 , in the present volume).

\section{Bibliography}

A. Corpus

\section{A.1. Old Romanian corpus}

A.1620 = Alexandria, în Zgraon, Fl. (ed.), Cele mai vechi cărți populare în literatura română, vol. 11, Fundația Națională pentru Știință și Artă, București, 2006.

вв.1688 = Biblia adecă Dumnezeiasca Scriptură a Vechiului și Noului Testament, tipărită întîia oară la 1688 în timpul lui Șerban Vodă Cantacuzino, Domnul Țării Românești, retipărită după 300 de ani în facsimil și transcriere cu aprobarea Sfîntului Sinod, această ediție văzînd acum, din nou, lumina tiparului, cu binecuvîntarea Prea Fericitului Părinte Teoctist, Patriarhul Bisericii Ortodoxe Române, 1988, București.

$\mathrm{CC}^{1} .1567-8=$ Coresi, Tûlcul evangheliilor și molitvenic românesc, ed. V. Drimba, Editura Academiei, București, 1998.

cC $^{2} .1581$ = Coresi, Cartea cu invățătură, ed. S. Pușcariu \& Al. Procopovici, Atelierele Grafice Socec, București, 1914.

CCat.1560 = Roman-Moraru, Al. (ed.) (1982). Catehismul lui Coresi, în Gheție, I. (coord.), Texte românești din secolul al XVI-lea, Editura Academiei Române, București, p. 21-97.

CII $1705=$ Dimitrie Cantemir, Opere complete, IV. Istoria ieroglifică, ed. S. Toma, București, 1974.

CIst.1700-50 = Constantin Cantacuzino, Istoriia Țărîi Rumânești, în Istoria Țărîi Rumâneşti atribuită stolnicului Constantin Cantacuzino, ed. O. Dragomir, Editura Academiei Române, București, 2006.

CL.1570 = Coresi, Liturghierul lui Coresi, ed. Al. Mareș, Editura Academiei, București, 1969.

CPr.1566-7 = Coresi, Texte de limbă din secolul XVI, IV. Lucrul apostolesc tipărit de diaconul Coresi la 1563, ed. I. Bianu, București, 1930.

CPrav.1560-2 = Coresi, Pravila (Brașov), ed. Gh. Chivu, în Gheție, I. (coord.), Texte românești din secolul al XVI-lea, p. 218230.

Ст.1560-2 = Coresi, Tetraevanghelul tipărit de Coresi, Brașov 1560-1561, comparat cu Evangheliarul lui Radu de la Mănicești. 1574, ed. Fl. Dimitrescu, Editura Academiei, București, 1963.

Cv.1563-83 = Costinescu, M. (ed.) (1981). Codicele Voronețean, Editura Academiei Române, București.

Dî = Chivu, Gh., Georgescu, M., Ioniță, M., Mareș, Al. \& Roman-Moraru, Al. (eds) (1979). Documente și însemnări românești din secolul al XVI-lea, Editura Academiei, București.

DPar.1683 = Dosoftei, Parimiile preste an, Iaşi, 1683, ed. M. Ungureanu, Editura Universității „Alexandru Ioan Cuza”, Iaşi, 2012.

DRH,B = Documenta Romania Historica. B. Țara Românească, Editura Academiei Române, București, 1985: vol. XXV (16351636); 1998: vol. XXX (1645); 2003: vol. XXXI (1646)

Ev.1642 = Gherman, A.-M. (ed.) (2011). Evanghelie invaățătoare (Govora, 1642), Editura Academiei, București.

FD.1592-604 = Floarea darurilor, în Roman Moraru, Al. (ed.) (1996). Cele mai vechi cărți populare in literatura română, 1 , Editura Minerva, București, p. 119-182.

Mărg.1691 = Ioan Gură de Aur, Mărgăritare, ed. R. Popescu, Editura Libra, București, 2001.

NT.1648 = Ion Neculce, Letopisețul, în Ion Neculce, Letopisețul Țării Moldovei și O samă de cuvinte, ed. I. Iordan, Editura de Stat pentru Literatură și Artă, București, ed. a II-a, 1959.

PB 1651 = Psaltirea de la Bălgrad, Editura Reîntregirea, Alba Iulia, 2001.

po.1582 = Pamfil, V. (ed.) (1968), Palia de la Orăștie, Editura Academiei Române, București.

Prav.1646 = Rădulescu, A. (ed.) (1961). Carte românească de invățătură, 1646, Editura Academiei, București.

Prav.1652 = Rădulescu, A. (ed.) (1957). In dreptarea legii, 1652, Editura Academiei, București.

Sind.1703 = Georgescu, M. (ed.) (1996). Sindipa, în Cele mai vechi cărţi populare în literatura română, I, Editura Minerva, București, p. 249-315.

ULM 1725 = Grigore Ureche, Letopisețul Țării Moldovei, ed. P.P. Panaitescu, București, 1955, p. 57-209.

VRC.1645 = Varlaam, Opere. Răspunsul împotriva catihismusului calvinesc, ed. M. Teodorescu, Editura Minerva, București, 1984. 


\section{A.2. Dialectal corpus}

AD I = Densusianu, Ov. (1915). Antologie dialectală, Atelierele Grafice Socec \& Co., București.

Bistrița-Năsăud = Marin, M. \& Tiugan, M. (1987). Texte dialectale și glosar Bistrița-Năsăud, Consiliul Culturii, Institutul de Cercetări Etnologice și Dialectologice, București.

Dobrogea = Lăzărescu, P., Neagoe, V., Pană, R. \& Saramandu, N. (1987). Texte dialectale și glosar Dobrogea, [f.e.], București.

Făgăraș-Transilvania = Tocilescu, G. G. \& Țapu, C.N. (1980). Materialuri folcloristice, Editura Minerva, București.

GN = Candrea, I.-A., Densusianu, Ov. \& Sperantia, Th. (1906-1907). Graiul nostru. Texte din toate părțile locuite de români, vol. I, Atelierele Grafice Socec \& Co., București.

HS = Marin, M. \& Tiugan, M. (2014). „Harta sonoră” a graiurilor și dialectelor limbii române, Editura Academiei Române, București.

Maramureș = Papahagi, T. (1925). Graiul și folklorul Maramureșului, Editura Cultura Națională, București.

Moldova \& Bucovina = Dumistrăcel, S., Hreapcă, D. \& Bîrleanu, I.-H. (1995). Noul atlas lingvistic român, pe regiuni. Moldova şi Bucovina. Texte dialectale, vol. I, partea II, Editura Academiei Române, Iași.

Muntenia = Bratu, M., Ghiculete, G., Marin, M., Marinescu, B., Neagoe, V., Pană, R., Tiugan, M. \& Vulpe, M. (1987). Texte dialectale. Muntenia, III, Editura Academiei Române, București.

Oltenia = Cazacu, B., Cohuț, C., Ghiculete, G., Mărdărescu, M., Şuteu, V. \& Vulpe, M. (1967). Texte dialectale. Oltenia, Editura Academiei, București.

Porțile de Fier = Cohuț, C. \& Vulpe, M. (1973). Graiul din zona „Porțile de Fier”, I. Texte. Sintaxă, Editura Academiei Române, București.

Tîrnave = Frăţilă, V. (2006). Graiul de pe Tîrnave. Texte și glosar, Editura Astra, Blaj.

\section{A.3. Literary language corpus}

Iordan, I. (1947). Limba română actuală. O gramatică a "greșelilor", Editura Socec \& Co., București.

Philippide, A. (1894). Istoria limbii române. Principii de istoria limbii, vol. I, Tipografia Naţională, Iaşi.

Roșu, Al. (2012). The RひB Success, Editura Mica Valahie, București.

\section{A.4. Online corpus}

B1 TV = B1 TV [online] (accesat 7 mai, 2017)

BF = Beniamin Fărăgău, Matei [online] (accesat 7 mai, 2017)

$\mathrm{BZ}=$ Bancul zilei, Ziarul Evenimentul [online] (accesat 7 mai, 2017)

$\mathrm{C}=$ Cotidianul $[$ online] (accesat 7 mai, 2017)

$\mathrm{EvZ}=$ Evenimentul zilei [online] (accesat 7 mai, 2017)

$\mathrm{G}=$ Gindul [online] (accesat 7 mai, 2017);

InfoV = Info Vaslui [online] (accesat 11 mai, 2017)

MG = Marian Godină, Facebook [online] (accesat 7 mai, 2017)

$\mathrm{P}=$ Publika [online] (accesat 11 mai 2017)

S = R. Ștef, A. Mureșan, Supraviețitorii. Mărturii din temnițele comuniste ale României, Editura Humanitas, București, 2014, [online] (accesat 7 mai, 2017)

$\mathrm{zC}=$ Ziua de Constanța [online] (accesat 7 mai, 2017)

\section{B. References}

Baños Baños, J.M. (ed.) (2009). Sintaxis del latín clásico, Liceus, Madrid.

DA = Pușcariu, S. (1913-1948). Diçționarul limbii române. A-Lojniţă, Librăriile Socec \& Comp. și C. Sfetea, București.

Densusianu, Ov. (1938). Histoire de la langue roumaine, II. Le 16-ème siècle, Leroux, Paris.

Dinică, A. (2017). Ipostaze morfologice ale formei veri în (daco) româna veche, in "Diacronia", 6, Sept. 30, art. A86, Crossref.

DLR = Iordan, I., Graur, Al., Coteanu, I., Sala, M. \& Mihăilă, Gh. (red. resp.) (1965-2010). Dicționarul limbii române. Serie nouă, Editura Academiei, București.

Ernout, A. \& Thomas, Fr. (1959). Syntaxe latine, Klincksieck, Paris.

Gast, V. \& Siemund, P. (2006). Rethinking the relationship between self-intensifiers and reflexives, in "Linguistics", vol. 44, iss. 2, p. 343-381, Crossref.

Hickey, R. (2010). Language contact: Reconsideration and Reassessment, in Hickey, R. (ed.), The Handbook of language contact, Wiley-Blackwell, Oxford, Crossref.

Manoliu-Manea, M. (1987). From conversational to conventional implicature: the Romanian pronouns of identity and their substitutes, in Giacalone, R.A., Carruba, O., Bernini, G. (eds), Papers from the 7th International Conference on Historical Linguistics, John Benjamins, Amsterdam, p. 419-428, Crossref.

Pană Dindelegan, G. (ed.) (2016a). The Syntax of Old Romanian, Oxford University Press, Oxford [anexe online].

Pană Dindelegan, G. (2016b). Feminine singular pronouns with neuter value, in Pană Dindelegan, 2016a, p. 611-618, Crossref.

Rusu, V. (coord.) (1984). Tratat de dialectologie românească, Scrisul românesc, Craiova. 
Sala, M. (coord.) (2001). Enciclopedia limbii române, Editura Univers Enciclopedic, București.

Spiță, D. P. (2003). Les connecteurs en français et en roumain. Plans d'organisation du discours, Institutul European, Iaşi.

Stan, C. (2013). O sintaxă diacronică a limbii române vechi, Editura Universității București, București.

Teiuș, S. (1980). Coordonarea în vorbirea populară românească, Editura Științifică și Enciclopedică, București.

Väänänen, V. (1981). Introduction au latin vulgaire, Editions Klincksieck, Paris.

Vasilescu, A. (2008). Pronumele și adjectivul pronominal de întărire, in Guțu Romalo, V. (coord.), Gramatica limbii române, Editura Academiei București, p. 218-222.

Vasilescu, A. (2013). Pronominal intensifiers, in Pană Dindelegan, G. (ed.), The Grammar of Romanian, Oxford University Press, Oxford, p. 404-407.

Vasilescu, A. (2015). Statutul lui „însuși” în textele românești din secolul al XVI-lea, in Sala, M., Stanciu Istrate, M. \& Petuhov, N. (eds), Lucrările celui de-al cincilea simpozion internațional de lingvistică, București, 27-28 septembrie 2013, Editura Univers Enciclopedic, București, p. 325-349.

Vasilescu, A. (2016a). Reciprocal constructions, in Pană Dindelegan, 2016a, p. 216-222, Crossref.

Vasilescu, A. (2016b). Nominal intensifiers, in Pană Dindelegan, 2016a, p. 386-393, Crossref.

Woodcock, E. C. (2005). A New Latin Syntax, Bolchazy-Carducci Publishers, USA.

Zafiu, R. (2005). Conjuncțiile adversative din limba română: tipologie și niveluri de incidență, in Pană Dindelegan, G. (coord.), Tradiție și inovație în studiul limbii române, Editura Universității din București, București, p. 239-252.

Zafiu, R. (2012). «Particula»-și: între intensificare și indefinire, in Zafiu, R., Dragomirescu, A., Nicolae, Al. \& Ștefănescu A. (eds), Limba română: direcții actuale în cercetarea lingvistică, I, Editura Universității din București, București, p. 277-285.

Zafiu, R. (2013). The pronominal intensifier insuşi, in Dobrovie-Sorin, C. \& Giurgea, I. (eds), A Reference Grammar of Romanian, vol. 1. The Noun Phrase, John Benjamins, Amsterdam / Philadelphia, p. 287-294, Crossref.

Zamfir, D.-M. \& Uță Bărbulescu, O. (2016). Din nou în legătură cu pronumele adins din limba română veche, in Constantinescu, M. V., Dragomirescu, A., Nicolae, Al., Stoica, G. \& Zafiu, R. (eds), Perspective comparative și diacronice asupra limbii române, Editura Universității din București, București, p. 419-429. 